\title{
Endoparasite fauna of Brycon amazonicus and $B$. melanopterus (Characidae, Bryconinae) from Negro and Solimões rivers, Amazon, Brazil
}

\author{
Thamy Santos RIBEIRO ${ }^{1 *}$, Bruno Hideo UEDA², Gilberto Cezar PAVANELLI ${ }^{3,4}$, \\ Ricardo Massato TAKEMOTO \\ Universidade Estadual de Maringá, Post-Graduation Program in Aquatic Environment Ecology, Nupélia, Colombo Avenue, 5790, Jardim Universitário, \\ Maringá, Paraná, Brazil 87020-900. \\ 2 Universidade Estadual de Maringá, Post-Graduation Program in Compared Biology, Nupélia, Colombo Avenue, 5790, Jardim Universitário \\ Maringá, Paraná, Brazil 87020-900. \\ ${ }^{3}$ Universidade Estadual de Maringá, Post-Graduation Programs in Inland Aquatic Environment Ecology and Compared Biology. Maringá, PR, Brazil 87020-900. \\ ${ }^{4}$ Centro Universitário de Maringá, Post-Graduation Program in Health Promotion, Maringá, PR, Brazil 87020-900 \\ *Corresponding author: thamysantos@yahoo.com.br
}

\begin{abstract}
Congeneric host species present similar biological and behavioral aspects, what may favor the presence of a similar parasite fauna. The aim of the present study was to compare the composition and structure of the parasite community from congeneric species, Brycon amazonicus and B. melanopterus, collected on the Negro and Solimóes Rivers. The fish internal organs were longitudinally opened and analyzed under stereomicroscope. The examination revealed that $B$. amazonicus was parasitized by Procamallanus (Spirocamallanus) inopinatus (26.7\% and 35.5\%), Contracaecum type $2(10 \%$ and $16.13 \%)$ and Rhabdochona acuminata $(0 \%$ and $3.23 \%)$, prevalence values for Negro and Solimóes River, respectively. The analysis of $B$. melanopterus, a fish species found only in the Solimóes River, revealed $P$. (S.) inopinatus (33.3\%), Contracaecum type $1(60 \%)$ and $R$. acuminata (3.34\%). These results indicate that the taxonomic proximity of the hosts was a stronger influence on the parasite species than external host environment.
\end{abstract}

KEYWORDS: Negro River, Solimóes River, 'matrinxâ’, metazoan parasites, nematode.

\section{Fauna endoparasitária de Brycon amazonicus e B. melanopterus (Characidae, Bryconinae) dos rios Negro e Solimões, Amazônia, Brasil}

\section{RESUMO}

Espécies hospedeiras congenéricas apresentam aspectos biológicos e comportamentais semelhantes, o que pode favorecer a presença de uma fauna de parasitas semelhantes. O objetivo do presente estudo foi comparar a composição e a estrutura da comunidade parasitária de espécies congêneres, Brycon amazonicus e B. melanopterus, coletados nos rios Negro e Solimões. Os órgãos internos dos peixes foram longitudinalmente abertos e analisados com o auxílio de estereomicroscópio. O exame revelou que B. amazonicus foi parasitada por Procamallanus (Spirocamallanus) inopinatus (26,7\% e 35,5\%), tipo Contracaecum 2 (10\% e 16,13\%) e Rhabdochona acuminata ( $0 \%$ e 3,23\%), os valores de prevalência para os rios Negro e Solimóes, respectivamente. A análise de $B$. melanopterus, uma espécie de peixe encontradas somente no Rio Solimóes, revelou $P$. (S.) inopinatus (33,3\%), Contracaecum tipo $1(60 \%)$ e $R$. acuminata (3,34\%). Estes resultados indicam que a proximidade taxonômica dos hospedeiros foi uma influência mais forte sobre as espécies de parasitas do que ambiente externo ao peixe.

PALAVRAS-CHAVE: Rio Negro, Rio Solimões, parasitos metazoários, 'matrinxã’, nematóides. 
The Bryconinae subfamily includes 74 nominal species, 42 of which are from the genus Brycon, an important group in almost all Brazilian river basins, with several examples used in the aquaculture industry (Bittencourt and Cox-Fernandes 1990; Gomes et al. 2000). Among these Bryconinae species are the 'matrinxâ' Brycon amazonicus Spix and Agassiz, 1829, and Brycon melanopterus Cope, 1872, two congeneric species that present similar length (about $35 \mathrm{~cm}$ ) and superposition on the feeding spectrum, with omnivorous behavior, feeding on fruits, seeds and arthropods (Santos et al. 2006). The similar diet may result on similar parasite faunas, as reported by a classic pattern, where the endoparasite species composition is influenced by the diet of the host (Dogiel 1961; Morand et al. 2000; Poulin 2011).

On the other hand, Santos et al. (2006) also found that these two Brycon species differ in some behavioral aspects, such as the sedentary behavior of $B$. melanopterus, while $B$. amazonicus performs reproductive migration on the flood season, also dispersing to the rivers during the dry season. Several studies have observed that the reproductive migration pattern of a host can be a determining factor in the composition and structure of parasite communities, as the short and long migrations performed by this species over its lifetime permit the fish to exploit diverse environments, increasing the possibility of infection/infestation by diverse species of parasites (Lizama et al. 2006). Consequently, these divergent migratory characteristics may affect the endoparasite fauna, as related species usually exhibit divergent characteristics that make the coexistence possible (Dogiel 1961; Balassa et al. 2004).

The parasite fauna of these Brycon species is not yet well known - as most of the published studies regarding the parasite fauna of the Brycon genus were conducted on fish farms or were based on taxonomic descriptions (Andrade et al. 2001; Lemos et al. 2007; Milanin et al. 2010).

The aim of the present study was to test the hypothesis that the parasite fauna of two congeneric species will be more similar than the parasite fauna of two different environments. For this, it was analyzed the main characteristics of the endoparasites community, such as richness, abundance, diversity and dominance, from two species of Brycon genus.

Thirty specimens of $B$. melanopterus and 31 specimens of $B$. amazonicus were collected in the Solimôes River, on February 2012 and September 2013, respectively. Thirty one individuals of $B$. amazonicus were collected in the Negro River, on September 2013. All the collections were performed with help of local fishermen and some fishes were deposited in the collection of Nupélia.

After the taxonomic identification of fish, the parasitological procedures were performed according to Eiras et al. (2006). The use of the terms 'component community' and 'infracommunity', as well as the calculation of the prevalence, mean intensity, mean abundance and richness value, were all according to Bush et al. (1997). Prevalence is the number of hosts infected by a particular parasite species divided by the number of hosts examined. Mean intensity is the average intensity of a particular species of parasite among the infected host. Mean abundance is the total number of individuals of a particular parasite species in a sample of a particular host species divided by the total number of hosts of that species examined. The diversity was inferred according to the Brillouin index $(\mathrm{H})$ to each infracommunity from each collection site (Zar 1996). These $\mathrm{H}$ values were statistically compared by Kruskall-Wallis analysis on the $\mathrm{R}$ program version 3.1.0 (significance level $\mathrm{p}<0.05$ ).

The analysis of the $B$. amazonicus demonstrated that this fish species presented a parasite richness of three species: Procamallanus (Spirocamallanus) inopinatus Travassos, Artigas and Pereira, 1928, Contracaecum type 2 of Moravec, Kohn and Fernandes, 1993 and Rhabdochona acuminata (Molin, 1860). While $P$. (S.) inopinatus was observed in all the collection sites, $R$. acuminata was found only on the Solimóes River. The higher prevalence indices were observed in B. amazonicus and B. melanopterus from the Solimóes River, but the mean intensities and mean abundances were quite similar in all the collection sites - except for the $R$. acuminata, which presented the highest mean intensity level (Table 1).

The analysis of the B. melanopterus internal organs revealed that this host also presented a parasite richness of three species: $P$. (S.) inopinatus, $R$. acuminata and Contracaecum type 1 of Moravec, Kohn and Fernandes, 1993. The parasite indexes demonstrated that Contracaecum type 1 was the most prevalent nematode observed for $B$. melanopterus collected on the Solimôes River, followed by P. (S.) inopinatus (Table 1).

The higher prevalence levels were observed on $P$. (S.) inopinatus infecting $B$. amazonicus and Contracaecum larvae type 1 infecting $B$. melanopterus, both on Solimóes River. Rhabdochona acuminata presented the lower levels of prevalence, with no record on Negro River.

The Brillouin index demonstrated that the most diverse fauna was observed on both host species, $B$. amazonicus $(\mathrm{H}=0.29)$ and $B$. melanopterus $(\mathrm{H}=0.19)$, collected on Solimóes River, but the Kruskall-Wallis test revealed no statistical difference between the diversity of each host from each collection site $(\mathrm{p}=0.27 ; \mathrm{H}=3.94)$, what corroborates the null hypothesis - the parasite diversity of the two collection sites was not statistically different. For $B$. amazonicus, there was a dominance of $P$. (S.) inopinatus on all the collection sites, while for $B$. melanopterus there was a dominance of Contracaecum type 1 (Table 1). 
Table 1. Parasite fauna of Brycon amazonicus and B. melanopterus collected in Negro and Solimões River, with their respective infection sites, prevalence (P), mean intensity (MI) and mean abundance (MA). The hyphen means that the parasite species was not recorded in this host/local.

\begin{tabular}{|c|c|c|c|c|c|c|c|c|c|c|}
\hline \multirow{3}{*}{ Parasite } & \multicolumn{7}{|c|}{ Brycon amazonicus } & \multicolumn{3}{|c|}{ Brycon melanopterus } \\
\hline & \multirow[t]{2}{*}{ Infection site } & \multicolumn{3}{|c|}{ Negro River $(n=31)$} & \multicolumn{3}{|c|}{ Solimões River $(n=31)$} & \multicolumn{3}{|c|}{ Solimões River $(\mathrm{n}=30)$} \\
\hline & & $\mathrm{P}(\%)$ & $\mathrm{Ml}$ & MA & $\mathrm{P}(\%)$ & $\mathrm{Ml}$ & MA & $\mathrm{P}(\%)$ & $\mathrm{Ml}$ & MA \\
\hline Procamallanus (Spirocamallanus) inopinatus & Intestine & 26.70 & $\begin{array}{c}2.62 \\
( \pm 0.4)\end{array}$ & $\begin{array}{c}0.70 \\
( \pm 0.3)\end{array}$ & 35.50 & $\begin{array}{c}2.19 \\
( \pm 0.6)\end{array}$ & $\begin{array}{c}0.77 \\
( \pm 0.3)\end{array}$ & 33.33 & $\begin{array}{c}1.3 \\
( \pm 0.6)\end{array}$ & $\begin{array}{c}0.43 \\
( \pm 0.1)\end{array}$ \\
\hline Contracaecum type 1 & Mesenterium & - & - & - & - & - & - & 60 & $\begin{array}{c}3.6 \\
( \pm 0.4)\end{array}$ & $\begin{array}{c}0.60 \\
( \pm 0.2)\end{array}$ \\
\hline Contracaecum type 2 & Mesenterium & 10.00 & $\begin{array}{c}1.34 \\
( \pm 0.1)\end{array}$ & $\begin{array}{c}0.14 \\
( \pm 0.1)\end{array}$ & 16.13 & $\begin{array}{c}1.20 \\
( \pm 0.2)\end{array}$ & $\begin{array}{c}0.20 \\
( \pm 0.1)\end{array}$ & - & - & - \\
\hline Rhabdochona acuminata & Intestine & - & - & - & 3.23 & $\begin{array}{c}13.00 \\
( \pm 0.1)\end{array}$ & $\begin{array}{c}0.42 \\
( \pm 0.2)\end{array}$ & 3.34 & $1( \pm 0.5)$ & $\begin{array}{c}0.04 \\
( \pm 0.0)\end{array}$ \\
\hline
\end{tabular}

It is commonly said that hosts with similar biological and behavioral aspects present similar parasite fauna (Poulin 2011), and this affirmation was corroborated by the results here presented. Regardless the fact that $B$. amazonicus performs migrations on the reproductive period, and B. melanopterus presents a more sedentary behavior, the similarity between the hosts diet had a more important impact on the resemblance of the parasite fauna. This conclusion is also reinforced by the absence of statistical differences on the parasite diversity between the collection sites, what evidences that different environments, with different physic-chemical characteristics, is not an impediment to similar parasite diversity for the parasite species observed on the present study.

Procamallanus (S.) inopinatus was also observed on Brycon cephalus on the Negro and Solimóes Rivers and on $B$. amazonicus collected on raised system (Andrade et al. 2001; Andrade and Malta 2006). Comparing these results with the present study it can be observed that the endoparasite fauna of Brycon species is not rich. Besides, some of these parasites, such as $P$. (S.) inopinatus, are not exclusive to the Brycon genus, also occurring on other 44 hosts from Amazon hydrographic basin, such as Salminus brasiliensis, Astronotus ocellatus and Hoplias malabaricus (Thatcher 2006), three fish species with a strong commercial importance; these records, along with the present results, may indicate a low specificity and biological characteristics that allow this widespread presence.

The present study records for the first time the presence of Contracaecum larvae on Brycon species on the Amazon hydrographic basin, but this register only emphasizes the low specificity of this parasite, as this species has already been recorded on several host from the Amazon basin (Thatcher 2006). This larva belongs to the Anisakidae family, a taxonomic group well known for its zoonotic potential.
Many studies have described that the characteristics of the Solimóes River are favorable for aquatic fauna and flora, such as high suspended sediment, salt and organic matter load (Leenheer and Santos 1980; Hedges et al. 1994), while the Negro River presents a general depletion of the species, which is associated to the low concentration of dissolved salts and absence of suspended matter, low pH and the high concentrations of humic compounds (Leon et al. 2006). These abiotic advantages that support a higher diversity on the Solimóes River may have influenced the parasite fauna of B. amazonicus on the present study, as the Brillouin diversity index established that the parasite fauna was more diverse in the hosts of this local.

The present study demonstrated that, despite the different rivers where the fishes were collected, the endoparasite fauna was similar. Corroborating the hypothesis, the taxonomic proximity of the hosts was a stronger influence on the parasite species than external host environment.

\section{ACKNOWLEDGEMENTS}

The authors thank the structural support from the Núcleo de Pesquisas em Limnologia, Ictiologia e Aquicultura (Nupélia) and the financial support from Fundação Araucária (n 261/2012, Protocol n 2277.3). The PhD scholarships were financed by the Conselho Nacional de Desenvolvimento Científico e Tecnológico (CNPq), the Coordenação de Aperfeiçoamento de Pessoal de Nível Superior (CAPES).

\section{REFERENCES}

Andrade, S.M.S.; Malta, J.C.O.; Ferraz, E. 2001. Fauna parasitológica de alevinos de matrinxã, Brycon cephalus (Günther, 1869) coletados nos rios Negro e Solimóes, na Amazônia Central. Acta Amazonica, 31: 263-273.

Andrade, S.M.S.; Malta, J.C.O. 2006. Parasite fauna monitoring of matrixã Brycon amazonicus (Spix e Agassiz, 1829) raised in an intensive husbandry system in a stream channel in the State of Amazonas, Brazil. Brazilian Journal of Biology, 66: 1123-1132. 
Balassa, G.C.; Fugi, R.; Hahn, N.S.; Galina, A.B. 2004. Dieta de espécies de Anostomidae (Teleostei, Characiformes) na área de influência do reservatório de Manso, Mato Grosso, Brasil. Iheringia, Série Zoologia, 94: 77-82.

Bittencourt, M.M.; Cox-Fernandes, C. 1990. Peixes migradores sustentam pesca comercial. Ciência Hoje, 11: 20-24.

Bush, A.O.; Lafferty, K.D.; Lotz, J.M.; Shostak, A.W. 1997. Parasitology meets ecology on its own terms: Margolis et al. revisited. The Journal of Parasitology, 83: 575-583.

Dogiel, V.A. 1961. Ecology of the parasites of freshwater fishes. In: Dogiel, A.A.; Petrushevski, G.K.; Polyanski, Y.I. (Ed.). Parasitology offishes. Olivier e Boyd, Edinburgh, London, p.1-47.

Eiras, J.C.; Pavanelli, G.C.; Takemoto, R.M. 2006. Métodos de estudo e técnicas laboratoriais em parasitologia de peixes. $2 \mathrm{da}$ ed. EDUEM, Maringá. 199 p.

Gomes, L.C.; Baldisserotto, B.; Senhorini, J.A. 2000. Effect of stocking density on water quality, survival, and growth of larvae of the matrinxã, Brycon cephalus (Characidae), in ponds. Aquaculture, 183: 73-81.

Hedges, J.I.; Cowie, G.L.; Richey, J.E.; Quay, P.D.; Benner, R.; Strom, M.; Forsberg, B.R. 1994. Origins and processing of organic matter in the Amazon River as indicated by carbohydrates and amino acids. Limnology and Oceanography, 39: 743-761.

Leenheer, J.A.; Santos, U.D.M. 1980. Consideraçôes sobre os processos de sedimentação na água preta ácida do rio Negro (Amazônia Central). Acta Amazonica, 10: 343-55.

Lemos, J.R.G.; Dias, M.T.; Sales, R.S.A.; Nobre Filho, G.N.; Fim, J.D.I. 2007. Parasitos nas brânquias de Brycon amazonicus (Characidae, Bryconinae) cultivados em canais de igarapé do Turumã-Mirim, Estado do Amazonas, Brasil. Acta Scientiarum. Biological Sciences, 29: 217-222.

Leon, J.G.; Calmant, S.; Seyler, F.; Bonnet, M.P.; Cauhopé, M.; Frappart, F.; Filizola C.R.; Fraizy, P. 2006. Rating curves and estimation of average water depth at the upper Negro River based on satellite altimeter data and modeled discharges. Journal of Hydrology, 328: 481-496.

Lizama, M.A.P.; Takemoto, R.M.; Pavanelli, G.C. 2006. Influence of the seasonal and environmental patterns and host reproduction on the metazoan parasites of Prochilodus lineatus. Brazilian Archives of Biology and Technology,49: 611-622.

Milanin, T.; Eiras, J.C.; Arana, S.; Maia, A.A.; Alves, A.L.; Silva, M.R.; Adriano, E.A. 2010. Phylogeny, ultrastructure, histopathology and prevalence of Myxobolus oliveirai sp. nov., a parasite of Brycon hilarii (Characidae) in the Pantanal wetland, Brazil. Memórias do Instituto Oswaldo Cruz. 105: 762-769.

Morand, S.; Cribb, T.H.; Kulbicki, M.; Rigby, C.; Chauvet, C.; Dufour, V.; Faliex, E.; Galzin, R.; Lo, C.M.; Loyat, A.; Pichelin, S.; Sasal, P. 2000. Endoparasite species richness of New Caledonian butterfly fishes: host density and diet matter. Parasitology, 121: 65-73.

Moravec, F.; Kohn, A.; Fernandes, B.M.M. 1993. Nematode parasites of fishes of the Parana River (Brazil), 2: Seuratoidea, Ascaridoidea, Habronematoidea and Acuarioidea. Folia Parasitologica, 40: 115-134.

Poulin, R. 2011. Evolutionary ecology of parasites. Princeton University Press.

Santos, G.M.; Ferreira, E.J.G; Zuanon, J.A.S. 2006. Peixes comerciais de Manaus. Ibama/AM, ProVárzea, Manaus, Brasil. 144p.

Thatcher, V.E. 2006. Amazon fish parasites. Pensoft Publishers, Sofia, 580p.

Zar, J.H. 1996. Biostatistical analysis. Upper saddle river, 3. Ed. Prentice Hall, Inc., New Jersey.

Recebido em 02/06/2015

Aceito em 01/07/2015 